\title{
Institutional Inertia: Persistent Inefficient Institutions in Spain
}

\author{
JosÉ-Antonio Espín-SÁnCHEZ
}

In 1966, after more than 700 years, the irrigation community in Mula (Spain) switched from auctions to quotas to allocate water from its river. This change happened in the absence of either political or technological change. Quotas were more efficient, but required that farmers own water property rights. I develop a model in which poor farmers cannot credibly commit to purchase water rights. I show that empirical evidence on savings and prices is consistent with this interpretation. A temporary increase in output prices in the 1950s and better financial institutions allowed farmers to accumulate savings and solve the commitment problem.

"There is nothing more difficult to arrange, more doubtful of success, and more dangerous to carry through, than to initiate a new order of things."

Niccolò Machiavelli, The Prince

$\mathrm{T}$ he literature on institutional persistence has grown in recent years. This is not a new topic (North 1990; Alston, Eggertsson, and North 1996), but it was not until recently that an extensive set of empirical papers on the topic emerged. These new empirical papers focus on particular historical episodes and regions of the world, including India (Jha 2013), South America (Dell 2010), and Europe (Guiso, Sapienza, and Zingales 2008; Voigtländer and Voth 2012) among other areas. These papers document institutional persistence and present robust empirical results, but lack a formal mechanism that explains the persistence.

The Journal of Economic History, Vol. 77, No. 3 (September 2017). (C) The Economic History Association. All rights reserved. doi: 10.1017/S0022050717000705

José-Antonio Espín-Sánchez is Assistant Professor, Department of Economics, Yale University, 27 Hillhouse Ave Room 38, New Haven Connecticut 06511. E-mail: jose-antonio. espin-sanchez@yale.edu.

I am indebted to my advisor, Joel Mokyr, for helpful discussions, guidance, and support. I am also grateful to the members of my dissertation committee, Joseph Ferrie, Regina Grafe, and Robert Porter, for advice and encouragement. Discussions with Javier Donna, Tim Guinnane, Alejandra Irigoin, Naomi Lamoreaux, and Yannay Spitzer, as well as participants at Northwestern University and Universidad Carlos III Economic History Workshops, the WEHC 2012, and the SITE 2012 have greatly benefited this work. I would also like to express my gratitude to Javier Almela, Diego Caballero, Fernanda Donna, and Antonio Espín for their help collecting the data used in this project, and to Kelly Goodman, for editorial advice. I acknowledge financial support from Center for the Study of Industrial Organization at Northwestern University, the Agencia Estatal de Meteorología, and Fundación Caja Madrid. All errors are my own. 
In this article I provide a general framework to explain institutional persistence and institutional change. While I test the model through a particular empirical application, the model can be applied more generally. Traditional explanations for institutional persistence require technological or political change to spark institutional change. This article provides an alternative mechanism, called Institutional Inertia, which explains institutional change in the absence of political change or changes in technology or relative prices. In addition to providing an explicit mechanism for Institutional Inertia, this article also advances the notion of a transitional institution: a temporary institution whose sole purpose is to implement the change from the old institution to the new one.

I applied this model of institutional change to a particular historical case. In 1242 the Christian kingdom of Castile and the Muslim kingdom of Murcia signed a treaty stating that Murcia would become a protectorate of Castile. The treaty established that Castile would have political control over Murcia, but Muslims living there would keep their assets, their customs, and their lives. The Muslim governors of the cities of Mula and Lorca rejected the agreement. The Christian army then conquered both cities by force and expropriated the water property rights. In both towns, the conquerors then created a shareholder-owned corporation to hold the water property rights. The corporations in each town ran periodic auctions to sell water usage rights and paid dividends to the owners at the end of the year. All the other towns and cities in the region kept their pre-Reconquista system, in which land and water rights were linked and farmers periodically received a fixed amount of water, proportional to their land holdings.

Although most contemporaries believed that the auctions were inefficient and observed neighbors in most surrounding towns allocated water by fixed quota (fixed shares of water available), it was not until 1961 in Lorca and 1966 in Mula that the two cities implemented quotas. ${ }^{1}$ Hence, an inefficient institution persisted for more than 700 years.

In Mula, the old market institution of auctions did not require any restriction on the distribution of water property rights. The new non-

\footnotetext{
${ }^{1}$ Donna and Espín-Sánchez (2015) show that in this setting, quotas were more efficient than auctions. This was due to decreasing marginal returns on water and the homogeneity in productivity across farmers. Both systems were second-best institutions, and allowing for trading after allocating quotas would improve efficiency. Another concern would be that during a dry year quotas allocated the same amount per tree to all farmers, but this amount would not be enough to save any of the trees. If the market allocated enough water to some trees and zero water to the rest of the trees, then the market could be more efficient since it would save some trees. This is theoretically possible, but unlikely to hold in this setting since there had not been a drought so severe as to make the survival of all trees unfeasible.
} 
market institution of quotas, however, required a particular distribution of water property rights. Each farmer had to own water property rights proportional to the size of her land. If the agent (farmer) was poor, she faced a hold-up problem when she tried to buy water property rights from the principal (original owner or Waterlord). Since she could not pay in cash, she would promise to pay in the future, that is, take on debt. In the presence of uncertainty, however, a debt contract may solicit a suboptimal level of effort. Thus, the farmer would not be able to make the promised payment with certainty. The Waterlord would refuse such a contract. If the farmer owned the water property rights, she would exert the first-best level of effort and would thus have been able to pay the debt. Moreover, there was also a coordination problem among the farmers. In order to change the institution, farmers, collectively, needed to own a majority of water property rights.

While most scholars rely on a Hobbesian Leviathan to enforce contracts, Elinor Ostrom $(1990,2005)$ extensively studied the benefits of selfgoverning institutions like the one I am studying here. ${ }^{2}$ The model presented here fits within Ostrom's framework, but concerns the choice between two self-governed institutions (auctions and quotas) rather than the choice of whether or not to self-govern. Mula farmers allocated water through one self-governing mechanism or the other without the intervention of a third party. Moreover, farmers under each regime established their own courts and appointed their own judges. In this article, I focus on the conflict between water owners and farmers, taking each group as a single entity. That is, I take as given that farmers solved the collective action problem.

In general, in an institutional change, the principal's choice of institution affects both the principal's and agent's payoff. First, the principal chooses the institution, and then the agent makes a monetary transfer to the principal. In a world with perfect information, no bargaining costs and perfect commitment - one in which the Coase Theorem (Coase 1960) holds - the efficient institution is always put in place. The lack of institutional change in a non-Coasian world results from a misalignment of incentives between the principal and the agent. Institutional Inertia happens when the agent must have decision/property rights under the new institution, but cannot commit to pay the principal after the change from the old institution.

One way to solve this problem is for the agent and the principal to join forces. This will happen, for example, when the agent gains decision

\footnotetext{
${ }^{2}$ The Hobbesian legal centralism theory has been criticized by Ellickson (1991) among others. Moreover, Posner (2000) argues that there are situations in which people are not constrained by formal legal institutions, but by some commonly agreed social norms.
} 
rights: property rights or political power. When the agent has decision rights, the principal/agent distinction disappears and hence, the institution is efficient. This approach implicitly assumes that commitment is not possible. This is the approach taken in the political economy literature. Daron Acemoglu and James Robinson (2008) argued for the importance of commitment during institutional change. However, the mechanism proposed here requires a type of commitment different from theirs in two important aspects. First, they focus on the commitment ability of the principal (elite). In their model, the principal uses democracy as a commitment device to avoid expropriating agents (citizens) in the future. To the contrary, I focus on the commitment ability of the agent (farmer). Agents here use collateral or upfront payment as a commitment device to prevent them from shirking and to facilitate payback. Second, no transitional institution exists in their model. Thus, commitment ability is relevant only for the new institution (democracy). In this article, commitment plays no role in the old institution, or in the new one. Instead, commitment is only important for the transitional institution. Without a credible commitment from the agent (farmer), the principal will never agree to change from the old institution to the transitional institution.

Another explanation of institutional change focuses on technological change or changes in prices that affect principal/agent payoffs. In particular, if the agent's losses under the old institution are sufficiently large, the mechanism preventing the agent from adopting her preferred institution collapses. Thus, the benefits of the change offset the associated transaction costs. Notice that, for this argument to hold the agent must have commitment power. The agent must also receive gains big enough to cover the transaction costs. The New Institutional Economics (NIE) literature (see Menard and Shirley 2005) attributes institutional changes to changes in agents' relative payoffs and transaction costs. For example, Gary Libecap (1978) clearly demonstrated how the evolution towards a more precise definition of mineral property rights in the American West followed the discovery of ore veins. The more valuable the mineral rights, the greater the value of precise property rights relative to more imprecise ones. The greater the inefficiency gap, the greater the lobbying effort to introduce new legislation. Hence, changes in the relative payoffs of different institutions triggered an institutional change.

This article takes a third approach, overlooked in the literature, which would require an increase in the agent's commitment power. The agent under the new institution should compensate the principal and, since efficiency has increased, the agent's payment to the principal will be lower than the agent's gains. If the agent can credibly commit to compensate 
the principal, then the institutional change will occur. If the agent cannot commit to this payment, then an inefficient institution persists. This can happen even if it is common knowledge that the institution is, indeed, inefficient. Avner Greif (2006) studies Medieval Maghribi traders where the change in the principal's beliefs about whether or not the agent will honor their contract leads to a change in the agent's commitment ability. Both this article and Grief's advance the argument that a change in payoff or decision power is not needed to prompt the emergence of a new institution.

This condition for institutional transition - a change in property rights with the promise of a future payment - structurally resembles a debt contract. There is a transitional period - after the principal decides but before the agent pays off the debt-with different rules and incentives than those of either the old or new institution. The transitional institution, here the debt contract, is required only to change from the old to the new institution. In other words, both institutional inertia and a transitional institution only occurred when the new institution was more efficient and required the agent to own property rights.

\section{BACKGROUND}

Geographical, historical, and social conditions at the time the Christians conquered the Kingdom of Murcia had an important impact on the way institutions were initially set up according to Miguel Rodríguez Llopis (1998). After the separation of water and land ownership, the owners of water property rights (Waterlords) were different persons than the landowners (farmers) and a well-functioning water cartel was established. The Waterlords themselves began to run the auctions. In the nineteenth century, this cartel was formalized, legalized, and named Heredamiento de Aguas. The land-owners were small proprietors, with family-size plots, who created their own association in 1933, Sindicato de Regantes. The aim of this association was, on the one hand, to self-regulate and settle disputes which arose between neighbors and, on the other hand, to keep the balance of power in the market for water.

\section{Tandas (Quotas) and Subastas (Auctions)}

Contemporaries considered quotas the fairest institution. Water ownership was tied to land ownership. Every plot of land was assigned some amount of irrigation time during each tanda (a period of three weeks). The amount of irrigation time allocated to each farmer depended on the size of the plots she owned. However, the farmer's crop mix depended 
not on the plot size, but on the amount of water available for irrigation. For example, a tree takes several years to be fully productive, but can die in a given year without sufficient water. Other crops like tomatoes, which take a farmer three months to grow and harvest, incur no losses, beyond the cost of seeding, if the harvest is lost during a drought. Hence, a farmer with a secure supply of water plants trees and receives a higher expected return. This system had the advantage that every farmer periodically got some "fair" amount of water, a desirable feature during a drought. Because of the insurance property of this institution, farmers had the security needed to carry out risky investments such as planting trees.

The units sold in the auction refer to the right to use the water flowing through the river at a specific date and time, during a window of three hours. In Mula, water property rights were well established and were divided into 832 shares. The payment had to be made in cash, as specified in the Heredamiento's bylaws. The functioning of the cartel was similar to a modern corporation: votes were proportional to shares and shares were tradable.

\section{Environment}

Southeastern Spain is the most arid region of Europe. It is located to the east of a mountain chain, the Prebaetic System. The rainfall frequency distribution is asymmetric with most years dryer than the average. Rain occurs mostly during fall and spring. Despite the fact that the region is dry, rivers flowing down the Prebaetic System provide the region with enough water for irrigation in rainy years. More than 90 percent of the parcels in Mula were smaller than one hectare. There were more than 1,000 hectares of irrigated land in Mula in 1955: about 500 farmers had access to irrigated lands and bid frequently in the water auction, and the average plot had 2.4 hectares (see Table 1). About 97 percent of the farmers were owners of the land they cultivated, while 2.6 percent were tenants, and only 0.4 percent were sharecroppers. The environment made the moral hazard problem between the landowner and the tenant so important as to render a larger scale of land ownership unprofitable. ${ }^{3}$ Since the land was owned individually, but the water irrigation system (the river, the dam, and the channels) was managed jointly, farmers created an institution to manage the common resource. However, in neighboring nonirrigated areas the structure was radically different. Powerful landowners

\footnotetext{
${ }^{3}$ The argument that the monitoring costs of the reduction in effort when growing vines or fruit trees create diseconomies of scale also appears in Hoffman (1996) and Rosenthal (1990).
} 
TABLE 1

SUMMARY STATISTICS OF SELECTED VARIABLES

\begin{tabular}{lccccc}
\hline \hline Variable & Mean & SD & Min & Max & Obs. \\
\hline Rain $(\mathrm{mm})$ & 8.53 & 46.33 & 0.00 & 980.00 & 3,834 \\
Water price (pesetas) & 271.61 & 374 & 0.05 & 4,830 & 13,872 \\
Land extension $(\mathrm{ha})$ & 2.41 & 9.13 & 0.03 & 124.7 & 435 \\
Output price $($ pesetas $/ \mathrm{kg})$ & 15.07 & 222.52 & 0.02 & 5,700 & 964 \\
Production $(\mathrm{kg})$ & $5,569.70$ & $10,003.76$ & 0 & 110,000 & 1,000 \\
\# Trees & 161.49 & 493.45 & 1 & 12,300 & 946 \\
\hline
\end{tabular}

Notes and Sources: Rain data from the AEMET. Daily rainfall in the city of Mula at the De la Cierva Dam (1955-1966). Water price data from the Archivo Municipal de Mula, section Heredamiento de Aguas. Each observation refers to one cuarta sold during 1955-1966. Agricultural data includes Land extension, Output price, Production, and \# Trees. Computed from data from the Archivo Municipal de Mula, agricultural census of 1955. Notice that information regarding land extension was missing for 59 individuals.

hired seasonal workers to work on large estates and paid them wages just above their survival needs. These large estates were used to grow cereals and were not irrigated. The goods produced in the huertas (irrigated orchards) were also different than those produced in the large estates. Huertas produced mainly vegetables and fruits. They were also the main producers of white mulberry leaves during the silk booms in the sixteenth and nineteenth centuries. However, large estates produced mostly grain and fodder. Huertas produced goods heterogeneous in quality, while large estates produced homogeneous goods that yielded low profit per acre. The former's products (citrus and peaches) were very sensitive to weather conditions and required constant and close attention.

The optimal mechanism in this environment was to sell the firm to the agent. Samuel Calatayud and Salvador Garrido (2011) showed that this was indeed the case in eastern Spain. They further showed that all contracts in this type of environment required either that the farmer own the land or that the farmer had a long-term contract with the landowner providing compensation for all improvements. Such a long-term contract was roughly equivalent to the farmer owning the land. It would have been optimal for the farmers to own both water and land rights. However, farmers owned land rights, but not the more expensive water rights, because they were poor and could not commit to pay water owners back.

If a new economic institution could substantially improve Pareto efficiency, then in the absence of transaction costs, one would expect the new institution to be put in place. If those with the power to decide would be worse off under the new institution, the winners could compensate them to prevent them from blocking the change. The Waterlords could 
sell their water rights to the farmers. Farmers would then make undistorted decisions and, thus, increase output. However, in Mula, farmers were penniless and could only buy water rights with a promise of future payment.

One option would be to use land as collateral. On the one hand, this would imply that farmers should carry a lot of risk, since they can lose "everything" during a drought. On the other hand, it would be hard for the Waterlord either to take over the land or to sell it to someone else since most potential buyers would likely be in the same financial situation. Farmers might also be reluctant to collateralize their land. A debt contract also creates inefficiencies in production due to the risk that the farmers bear, even if they are risk neutral. In the likely case that the farmers are risk averse, this inefficiency will be even greater. In the stochastic world of agriculture where weather fluctuates and crop production is differentially sensitive to effort, a debt contract implies that farmers will get little or none of the output produced in some states of the world. If this is likely, farmers would optimally choose to exert an inefficiently low level of effort. Hence, commitment problems can delay or make impossible an institutional transition. In such a situation, the only way to achieve full efficiency would be to give the water rights to the farmers, that is, give the firm to the agent, rather than sell the firm to the agent.

\section{Giving the Water to the Farmers}

Giving the water rights to the farmers for free was the proposition of the newly elected national government in 1931 when a new dam was built. The government made an offer to the Waterlords of 4.2 million pesetas for all the water rights of the Mula River. ${ }^{4}$ After the purchase, the government would give water rights to the farmers in proportion to the size of their land holdings, and water property rights would be tied to land property rights. Hence, the commitment problem would be solved and the more efficient institution would be adopted. The offer was made after the creation of the Confederación Hidrográfica del Segura in 1927, a political organization with the aim of consolidating water management at the basin level. Antonio Gil Olcina (1993) argues that the existence of such political organizations increasingly restricted the property rights of the Waterlords. This meant an increase in the Waterlords' willingness to sell their water rights. The creation of the Confederación also facilitated the creation of the farmers' association (Sindicato de Regantes) in 1933.

\footnotetext{
${ }^{4}$ The Mula River is a tributary of the Segura River, the main river in the region.
} 
The Waterlords took the offer seriously. They printed a small book with the details of the offer, the opinion of the president and other members of the council, and the main conclusions reached during meetings prior to a vote of the general assembly. The opinion of the water owners split into three groups. The group of small owners (one or two shares) was in favor of the sale, at any price. Since these owners were also farmers owning a small number of water shares, they would have benefited greatly from the change. Not only would they have received money from their shares, they would have also been awarded more water rights than they had before. The group of medium owners (three or four shares) was also in favor. Many of them were farmers, and would have received roughly the same amount of water rights as under the auction system, but they would have been paid for the water they owned. The group of large owners (five or more shares) was in favor of the offer only if the price offered was sufficiently high and the payment was made in cash. The offer of 4.2 million pesetas was considered a "fair" price according to most of the large owners, and the offer was accepted by the Waterlords during their general assembly.

However, the sale was never completed. The Waterlords demanded payment in cash, but the government - the newly established Second Republic of Spain - could not afford to pay in cash. The government was unable to make a credible promise of future payment. The concerns of the Waterlords were justified: three months after the delayed payment was rejected, the government defaulted on its national debt. Had the Waterlords accepted the offer from the government, they would not have been repaid. Soon after, the civil war broke out and the prospects for change looked dimmer than ever.

\section{Transition}

By the 1950s and 1960s though, Spain was in the midst of an economic boom. The government's foreign policy began to change. Borders were opened and trade agreements drafted with the European Union and the United States. This situation produced an unprecedented boost in the Spanish economy: the Spanish Miracle. This boost was especially important for the farmers in Mediterranean Spain. Exports of fresh and dried fruit grew rapidly (see Morilla Critz, Olmstead, and Rhode 1999). For the first time in their history, the farmers of Mula could produce enough output to create a surplus that could be saved. Improvements in the financial sector and a state policy directed towards increasing local savings and providing easy access to credit for small business created a favorable 
environment for savings. By 1966, the combination of the government's easy lending policy with a decade of Mula farmers' accumulated savings was enough to provide a credible promise of future payments.

After more than seven centuries of continuous operation, the auction mechanism came to an end in 1966. The farmers' union (Sindicato de Regantes) reached an agreement with the cartel (Heredamiento de Aguas), and the auction was replaced by a system of fixed quotas. Both parties agreed that the Sindicato would pay a fixed price for each cuarta of river water. The price would be revised every six months. The Sindicato then allocated water among the farmers using quotas.

The composition of the cartel of Waterlords did not meaningfully change during the years preceding the change. One can see in Figure 1 how the percentages of owners that have one, two, three, four or more than four shares are constant over time. ${ }^{5}$ After the Reconquista more than half of the shares of water rights belonged to the Marquis of Los Vélez. In the late nineteenth century the Marquis of Los Vélez sold all his shares to the Marquis of Pidal. By 1966, those shares belonged to the Marquis of Pidal and his sister.

The key to the transition was the credit line a savings bank extended the Sindicato. ${ }^{6}$ In 1966, the Sindicato signed an agreement with the bank for a credit line that could be used only for buying water property rights. Hence, in 1966 the Sindicato began buying each of the shares from the original owners. During the transition process from 1966-1981, farmers had to pay an extra fee, proportional to their land area, in order to repay the loan. By 1981, the association owned all the shares and formally changed the legal status of the water. Since then, the water of the Mula River has been tied to the land, in the pattern of other towns in Murcia. Farmers now only have to pay the operational costs of the system in proportion to their land area. They are now owners of both land and water.

\section{INSTITUTIONAL INERTIA AND THE EFFICIENCY OF TRANSITIONS}

This section concerns the problematic relationship between the farmers' association (Sindicato) and the Waterlord's association (Heredamiento). The main goal of this section is to use a simple model to show how the

\footnotetext{
${ }^{5}$ The data were collected using the remaining owners (shareholders) directories in the Archivo Municipal de Mula, section Heredamiento de Aguas. Every year the manager of the Heredamiento would compile a book with the names of the shareholders, and how many shares each of them had, as well as changes (private sales) from the previous year. I collected the information in the surviving documents to create the evidence in Figure 1.

${ }^{6}$ Information obtained via personal interview with the current president of the Sindicato, who is both a farmer and the son of the president of the Sindicato in 1966.
} 


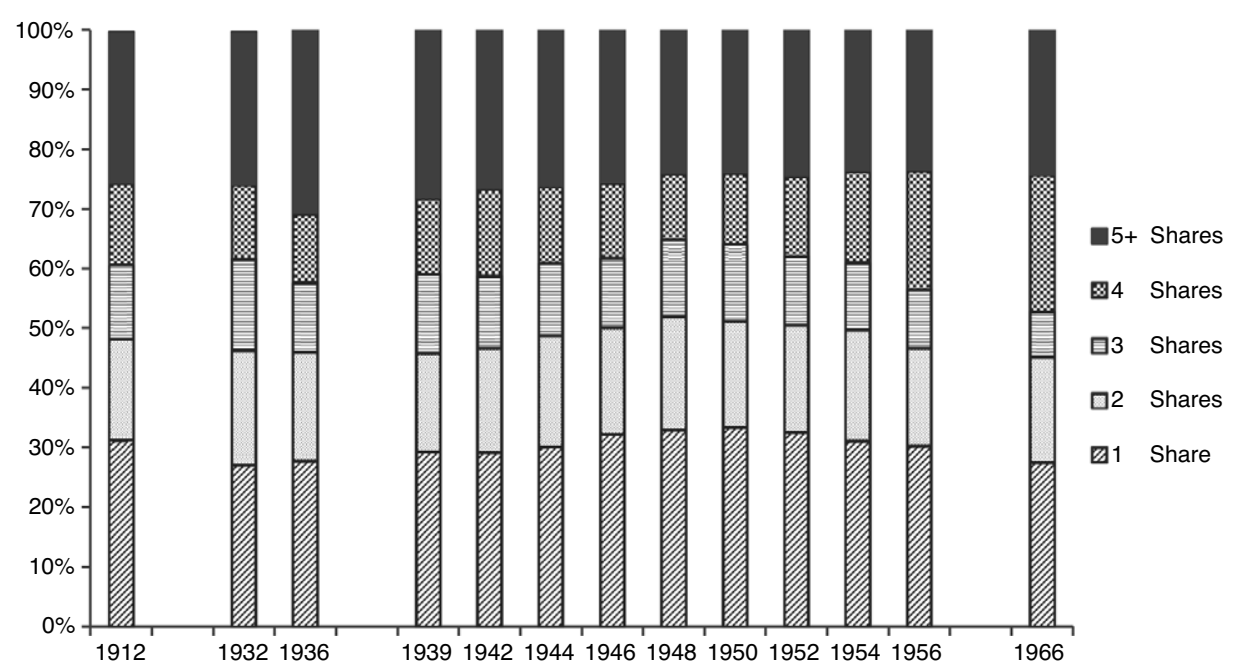

FIGURE 1

COMPOSITION OF WATER OWNERS BY HOLDINGS

DURING THE TWENTIETH CENTURY

Source: Computed from the data from the Archivo Municipal de Mula, Section Heredamiento de Aguas. Some years are missing.

holdup problem may arise and provide empirical predictions on the timing of an institutional change. The model is also informative to show that transitions to a new institution might be inefficient, even if the new institution is efficient, and to illustrate when a transition would be efficient.

For simplicity, I assume that the Heredamiento sells water rights as soon as it finds the prospect profitable. The production function in this economy $f(s, \theta, e)$ depends on the state of nature $s$, the water rights required for irrigation $\theta$, and the unobserved effort exerted by a farmer $e$; $s$ is a random variable that is realized after the agent has put in effort. The problem for each farmer is analogous up to the amount of water rights $\theta$ that the farmer needs. Hence, we can get rid of $\theta$ to simplify the notation: $f(s, \theta, e) \equiv f(s, e)$. There is a unit mass of farmers, thus the production function refers either to the individual farmer's production or the total production in the economy. The production function $f(s, e)$ is strictly increasing and concave in each argument.

The Heredamiento will act as the principal and will offer a contract to the Sindicato. The contract should be based on output, which is observable, but not on effort, which is unobservable. The contract chosen by the Heredamiento is a standard debt contract, that is, the Sindicato has to pay a fixed amount $B$. If the Sindicato does not pay $B$ (default), the Heredamiento incurs a bankruptcy $\operatorname{cost} C>0$ and takes over all the output. One can think of bankruptcy costs as all the legal and extra-legal costs 
that might be incurred in order to expropriate the output of the farmer and recover the ownership of the water rights, net of the discounted value of recovering the water rights. Some of the costs would be forgone earnings, legal fees, time spent in trials, and delay and uncertainty in a world with less than perfect enforcement of property rights. This standard debt contract is optimal in the present setting: it maximizes the set of parameters under which the sale will occur. ${ }^{7}$

The game has three stages. In the first stage, the Heredamiento offers a contract $B$ to the Sindicato, that is, the Heredamiento decides whether to sell the water rights to the Sindicato and the amount to be paid $B$. In the second stage, each farmer decides how much effort to exert, based on the contract, that is, $e \equiv e(B)$. In the third stage, after the uncertainty is realized, the Sindicato pays the Heredamiento the amount agreed $B$ or the Sindicato defaults and the Heredamiento gets the down payment from the Sindicato, all of the harvest, and pays the bankruptcy costs. ${ }^{8}$ The farmers have some wealth $D$ that they can use as a down payment. Let $A$ be the value that the Heredamiento assigns to the ownership of water rights which is equal to the expected discounted value of the water under the auction system. I focus on the case with $D<A$, otherwise the farmer could use her down payment to buy the water property rights and the transition to a more efficient institution would be trivial.

The Heredamiento asks the Sindicato for a payment $B$ after the output is realized. The Heredamiento incurs a risk because the Sindicato might not be able to pay the full amount $B$. Thus, in equilibrium we have $B+D \geq A$. The Heredamiento will sell the water rights whenever it is profitable to do so. This means that the selling price for the Heredamiento equals $A$. Notice that the price that farmers would pay for the water flow in a given year in a world without uncertainty ( $a=A / r$, where $r$ is the annual discount rate) is much lower than the discounted value of the water rights $A$.

\section{General Case}

The expected payoff of the Heredamiento is an increasing function of the level of effort exerted by the farmer. Hence, the Sindicato implicitly chooses the expected transfer. The Heredamiento sells the Sindicato the

\footnotetext{
${ }^{7}$ See Townsend (1979) and Gale and Hellwig (1985) for results on the optimality of the standard debt contract.

${ }^{8}$ For practical purposes we can think about the second stage as lasting 15 years, not one year. It would be unreasonable to expect that a farmer would be able to pay the total value of the water rights needed for irrigation after one year of production. A more precise model would have a payment due every year and the total loan due after $T$ years. It should also include penalties or renegotiation terms in case of partial default. This model would be more complicated and its predictions not different than those of the one-period model presented here.
} 
water rights $\theta$ and asks for a fixed amount $B$ to be paid after production occurs. Each farmer maximizes his utility $L(B)$ for a given level of debt $B$ by choosing effort optimally. The problem of each farmer is then

$$
V(B)=\operatorname{Max}_{e} V(e, B) \equiv \operatorname{Max}_{e}\left\{E_{s}[\max \{f(s, e)-B, 0\}]-D-e\right\},
$$

where the maximum is taken over the level of effort $e$ and the expectation is taken over $s$. The Sindicato pays $B$ and $D$ to the Heredamiento and keeps the rest of the output. If the Sindicato cannot pay $B$, that is, if $f(s, e)$ $<B$, then the Heredamiento will take the output and the down payment, after paying the bankruptcy costs, and the Sindicato will get nothing.

Incentive Compatibility (IC) requires that Heredamiento members should not be worse off selling their water rights

$$
W(e, B) \equiv E_{s}[\min \{B, f(s, e)-C\}]+D \geq A .
$$

In equilibrium the Heredamiento will be indifferent, hence equation 2 holds with equality. $W(e, B)$ is the payoff that the Heredamiento receives under contract $B$ when the farmer's effort is $e$. Notice that, for a fixed level of effort $e$, this is a zero-sum game when there is no bankruptcy, that is, the Heredamiento gets what the Sindicato does not, except for the bankruptcy costs $C$. One could explicitly include the future value of the water rights for the Heredamiento in case the farmer does not pay the debt. This value should be discounted to the bankruptcy costs. In other words, in the present form, the bankruptcy costs are net of the scrap value of water rights. ${ }^{9}$ With positive bankruptcy costs this is a negative-sum game whenever the bankruptcy costs are incurred in equilibrium with positive probability. The first-best (FB) level of effort of this game is equal to the level of effort that a farmer would exert if she owned water property rights equal to $\theta$, that is, $e^{F B}=\operatorname{argmax}_{e} e^{T W}(e)$.

If the farmer were the owner of the water, the farmer would maximize Total Welfare (TW)

$$
T W(e) \equiv V(B)+W(e, B)=E_{s}[f(s, e)]-e .
$$

Notice that the level of effort that the farmer will exert under a debt contract is never greater than the FB level, that is, $e(B) \equiv \operatorname{argmax}_{e} V(e, B)$ $\leq e^{F B}$. The farmer will exert the first-best effort if she always has a large

\footnotetext{
${ }^{9}$ If the second stage lasts 15 years, the present value of receiving back the property in 15 years would be very low due to discounting. For example, with a 10 percent discount rate the value would be just a fourth of the original value.
} 
enough down payment to cover the loan, that is, $f(s, e(B)) \geq B$, for all $s$. In this case, the problem of the farmer is identical to the first-best. Moreover, since there is no risk, the Heredamiento will ask for the minimum acceptable amount in the loan, that is, $B+D=A$. However, if the Sindicato does not have enough collateral, farmers may not be able to pay back loans with certainty. In this case the Heredamiento may ask for a payment greater than the value it assigns to the water rights in order to compensate for the risk.

We can solve the game by backward induction. We can write equation 2 as a function of $B$ only

$$
\underline{W}(B) \equiv E_{s}[\min \{B, f(s, e(B))-C\}]+D=A .
$$

We are interested in the lowest value of $B$ that satisfies this equation. Equation 4 will have no solution when the value that the Heredamiento assigns to the water rights $A$ is too big compared to the down payment $D$, when the reduction in output associated with the reduction in effort due to the hold-up is big, and when the bankruptcy costs $C$ are high. Let $\underline{D}$ be the minimum amount of down payment such that equation 4 has a solution. Under any level of down payment $D$ greater than $\underline{D}$, a transition will occur. ${ }^{10}$ This is the key result of the model.

The long persistence of this inefficient institution can be explained by the high-powered incentives present in this economy. Growing fruit trees is an effort-intensive activity, which is represented here by the concavity of the production function in effort. After paying for their living conditions, farmers did not have any money left over to save. Thus, they did not accumulate considerable savings to use as down payment until the 1960s. Without enough savings, farmers could not afford down payments large enough to commit to exert a high level of effort. Without the commitment, the Heredamiento would not agree to the contract. Finally, bankruptcy costs here act as a proxy for the quality of the financial institutions. It measures the costs that the lender faces if the farmer defaults on the loan. The improvements in financial institutions and the preferred treatment of rural loans during the 1960 s translate into lower bankruptcy costs.

\section{An Example}

I construct a numerical example to illustrate the implications of the model. The numbers do not have any relation with magnitudes in reality

\footnotetext{
${ }^{10}$ The result that down payments can be used to improve efficiency in the allocation of resources is not new in the finance literature (Stiglitz and Weiss 1981).
} 
but may help readers understand the model better. Let $f(s, e)=20 \cdot(s \cdot e)^{1 / 2}$. Where $s$ represents the amount of precipitation in the farmer's plot. The value of $s$ is 1 or 25 with equal probability. If the farmer owns the water rights, she will exert the first-best $(\mathrm{FB})$ level of effort $\left(e^{F B}=900\right)$ get an expected output of $E_{s}\left[f\left(s, e^{F B}\right)\right]=1800$, and obtain an expected surplus of $T W\left(e^{F B}\right)=900$. The value of owning water for the Heredamiento is lower than it is for the farmer: $A=800<900=T W\left(e^{F B}\right)$.

The first thing to notice is that the farmer will go bankrupt when $s=$ 1 if $B>600$. That is, if the debt is too high to be paid in full in the low productivity state, then the farmer will default. When $B \leq 600$ the farmer will never default and will always be the residual claimant of the output. Hence, she will put in the first-best level of effort. If $B>600$ then the farmer will be the residual claimant of the output only when $s=25$, hence she will put in the second-best (SB) level of effort at most. If $B>1250$ the farmer's expected utility is negative. Even though she is the residual claimant of the output when $s=25$, the output that she would receive in this case would not be enough to offset the effort cost. Hence, the effort of the farmer as a function of the contract offered is

$e(B)=\mid \begin{array}{ccc}e^{F B}=900 & \text { if } & B \leq 600 \\ e^{S B}=625 & \text { if } & 600<B \leq 1100+C-2 \cdot D \\ 0 & \text { if } & B>1100+C-2 \cdot D\end{array}$

when $D=0$, the farmer does not have any savings to use as a down payment. However, the Heredamiento needs at least 800 in expectation, that is, $B \geq 800$, and thus the farmer exerts at most the second-best effort. Under this contract the farmer does not get any output when $s=1$. With this result equation 2 becomes

$$
W_{0}(e, B) \equiv 0.5 \cdot[\min \{B, 500-C\}+\min \{B, 2500\}] \leq 800 .
$$

The minimum value of $B$ that satisfies this equation is $B=1100+C$. Hence, equation 4 has no solution when $D=0$ and $C>150$. In other words, if the Heredamiento offers a contract with $B>1250-2 \cdot D$ the farmer will not exert any effort and the Heredamiento will get nothing. If the Heredamiento offers a contract with $B<1100+C-2 \cdot D$, the expected value would be lower than the value of keeping the water rights and running the auction. Hence, when $C>150$ and $D=0$, the Heredamiento will not sell the water rights to the farmer under any future payment $B$. The key point is that high bankruptcy costs and a low down payment imply no institutional change. 


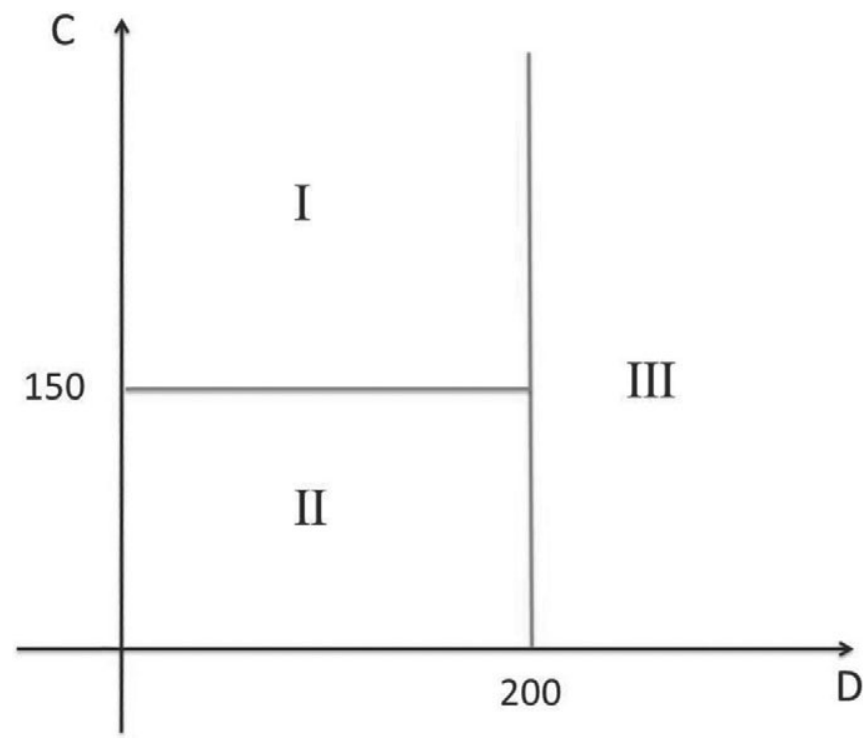

FIGURE 2

POSSIBLE EQUILIBRIA

Notes and Sources: Possible Equilibria: I No Institutional Change; II Institutional Change with Inefficient Transition; III Efficient Institutional Change. C corresponds to bankruptcy Costs; D corresponds to down payment.

When $D=0$, bankruptcy costs need to be low in order to have institutional change. Moreover, there is a threshold in the bankruptcy costs that triggers the institutional change. When $D=0$ an institutional change can happen if $C$ is low enough, but the farmer does not exert the first-best level of effort. If the down payment is high enough, the Sindicato will be the residual claimant in all states, and thus will never default. Moreover, when $D \geq 200$ the Heredamiento will offer a contract with $B \leq 600$ and the farmer will exert the first-best level of effort. Notice that, since the farmer will never default in equilibrium, the bankruptcy costs are irrelevant in this case.

Figure 2 shows all the possible equilibrium outcomes depending on the parameters of the model. There are three cases. ${ }^{11}$

I. $C>150$ and $D<200$. No institutional change is possible.

II. $C \leq 150$ and $D<200$. Institutional change with inefficient transition happens (SB).

III. $D \geq 200$. Efficient Institutional change happens (FB).

${ }^{11}$ When $D>200$ and $C<150$ an institutional change with inefficient transition could happen. However, such a contract will give the principal the same expected payoff as the efficient contract but will give the agent a lower output during the transition. 
An efficient institutional change will happen only when the farmers have enough savings to use as a down payment, regardless of bankruptcy costs. The shapes of the indifference equations are specific to the modeling choice of financial imperfections as bankruptcy costs, but the qualitative results are valid under more general specifications. In particular, since there are only two realizations of rain, there is only one level of secondbest effort. If the distribution of rain were continuous, there would be a minimum level of debt $\underline{B}$, below which the agent would exert first-best effort; a maximum level of debt $B^{+}$, above which the agent will not exert any effort; while the agent will exert intermediate levels of effort for intermediate levels of debt $B$.

\section{Institutional Inertia}

The model presented earlier shows that, even in a world with complete contracting (Hart 1988), a mutually beneficial arrangement cannot be reached if there are commitment issues. These issues are generated by limited liability. In other words, the punishment that the Heredamiento can use against the farmer in case of default is limited. This problem vanishes if the farmer has enough wealth to use as collateral. In general, moral hazard or default risk can create problems of hold-up, like the one presented here. This hold-up would apply to any misallocation of property rights. What created the Institutional Inertia is the combination of a hold-up problem in allocating the property rights and the fact that the efficient institution (quotas) requires a specific distribution of property rights. Institutional Inertia is then a situation where a more efficient distribution of water property rights cannot emerge due to the potential winners' inability to commit.

Efficiency under quotas requires the distribution of water property rights to be egalitarian, when farmers have homogeneous productivity. However, contractual problems may block a new, efficient distribution of water property rights. Moreover, auctions can be run under any distribution of water property rights. Therefore, the inverse transition (from quotas to auctions) could always have been achieved without delay, if auctions were more efficient than quotas. When farmers are heterogeneous in productivity, efficiency requires the expected marginal productivity to be equal among all farmers. Hence, more productive farmers will have greater quotas. In the years following the Reconquista, this was indeed the case in Murcia. There were up to seven different categories of land quality that were assigned different levels of water per land unit. 
The farmers also had to pay their share of maintenance cost proportional to water received, not to land owned. ${ }^{12}$

Institutional Inertia is asymmetric. Imagine a scenario with several towns. Initially, in each town, both the allocation of water property rights and of the original institution (quotas or auctions) is established arbitrarily. Quotas require the allocation of water property rights to be egalitarian. Farmers start with no wealth, but can save some money over time. If auctions were more efficient than quotas, then the towns in which the original institution was quotas will immediately change to auctions because auctions (or markets more generally) can function with any distribution of water ownership. In other words, the price in the auction would be the same regardless of whether all the shares in the Heredamiento are owned by one person or each shared is owned by one person. In this case there is no Institutional Inertia. However, if quotas are more efficient than auctions, towns with auctions will not switch to quotas until farmers have saved enough to use savings as down payment.

In summary, according to the model, several factors affect the likelihood of institutional change. First, the greater the savings of the farmer, the greater the amount available for collateral. With a larger down payment, the probability that a transition happens is higher.

Second, a change in $f(\cdot)$ can be interpreted as a change in output prices or a change in technology. However, the effect of a change in the production function on the likelihood of the institutional change is ambiguous. An increase in output prices will increase both the value of water for the Waterlords $A$ and for the farmers $V$.

Third, a more equal distribution of water property rights implies that many farmers already own water property rights. Hence, the transition is more likely to happen. Fewer farmers face a hold-up and there are more farmers who are members of the water cartel and would thus vote in favor of the change. This idea is not in the model which, for simplicity, focuses on homogeneous farmers.

Finally, in the analysis presented earlier, there is an implicit assumption that lenders earn zero profits in expectation. Greater bankruptcy costs and lender profits mean the transition is less likely. A more developed financial system and cheaper access to credit thus imply that the transition is more likely. In the next section, I provide empirical evidence on each of these factors.

\footnotetext{
12 This practice disappeared from all towns during the nineteenth century (Ruiz-Funés 1916), which suggests that changes in technology during that century made all the land of similar quality.
} 


\section{EMPIRICAL EVIDENCE}

\section{Savings and Living Conditions}

Figure 3A shows the available data on deposits in rural banks. Only farmers were depositors of rural banks, whose structure was similar to rural credit cooperatives. It shows the average real deposits per account. The evolution of average real deposits was erratic during the last quarter of the nineteenth century, but deposits decreased during both the SpanishAmerican War (1898) and during WWI (1914-1917). The fast recovery after WWI was truncated during the Spanish Civil War (1936-1939), but it began to recover after WWII (1939-1945). By the 1960s, real deposits reached historical maximums and continued to grow. It was remarkable that deposits in Murcia began from a lower level in the 1940s, but quickly caught up and overtook the national average during the late 1950s and the 1960s. ${ }^{13}$

The graph makes clear that, however erratic and dependent on the macro-environment deposits were, the uniform growth beginning in the 1950s was unprecedented. Living conditions, in addition to the savings of the lower and middle classes, improved during the 1950s and reached a new standard by 1960. This growth was important for Murcia, where both measures initially lagged the national average before catching up by 1957 and then surpassing it.

As mentioned earlier, the government offered to buy Mula water rights for 4.2 million pesetas in 1931 and there were about 500 farmers. Prices increased 10,907 percent during 1931-1966. Thus, the value of the average water rights per farmer was more than 90,000 pesetas in 1966. By 1966 the average farmer had 12,000 pesetas deposited in a savings bank in Murcia (Figure 3A). Then, an average farmer in 1966 has enough savings to make a down payment of 13 percent of the value of the principal. Notice that this figure is a historical maximum in real terms, and that $10-15$ percent is also the usual magnitude required for down payments for mortgages.

\section{Changes in Prices}

An increase in output prices unambiguously increases farmers' revenues and thus their savings, whether it is permanent or temporary. A

\footnotetext{
${ }^{13}$ The data available correspond to the evolution of the average deposit in the region, not the individual deposits of the farmers in Mula. I am implicitly assuming that the evolution of the farmers' deposits follows the evolution of the average deposit. This is a reasonable assumption since these farmers fall within the target audience of depositors at public savings banks.
} 
A) Average Real Deposits in Rural Banks in Murcia and Spain

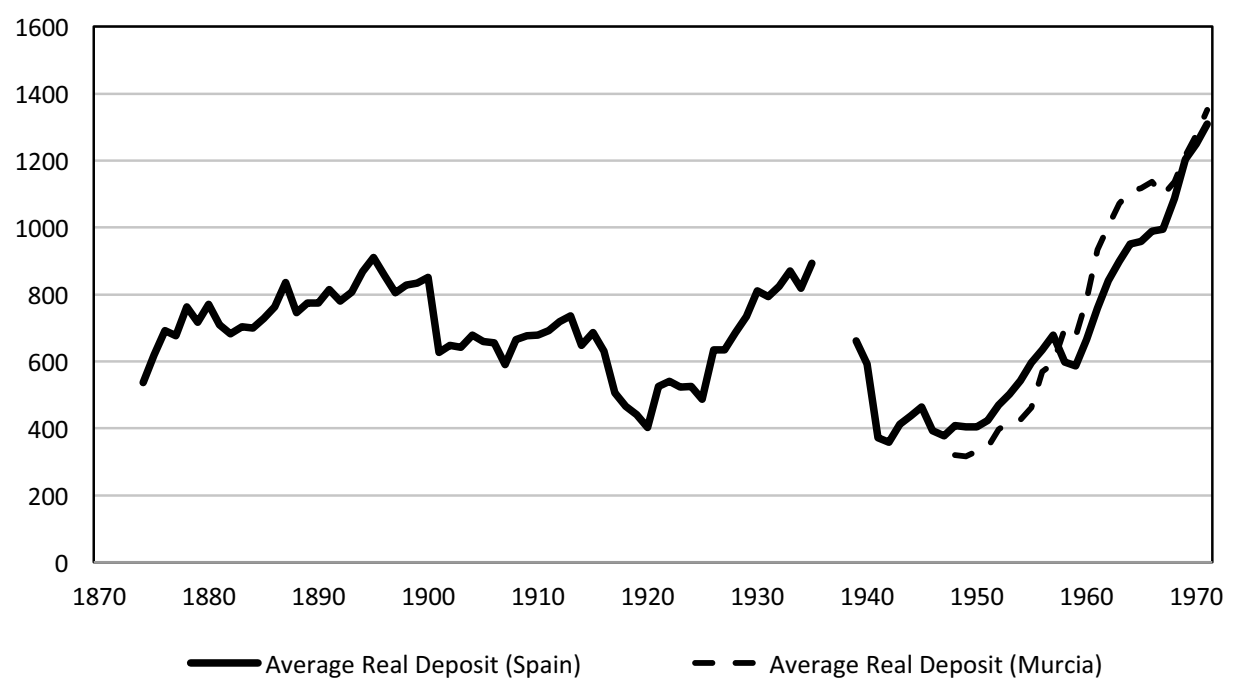

B) Evolution of Rural Loans and Deferred Rural Loans in Spain
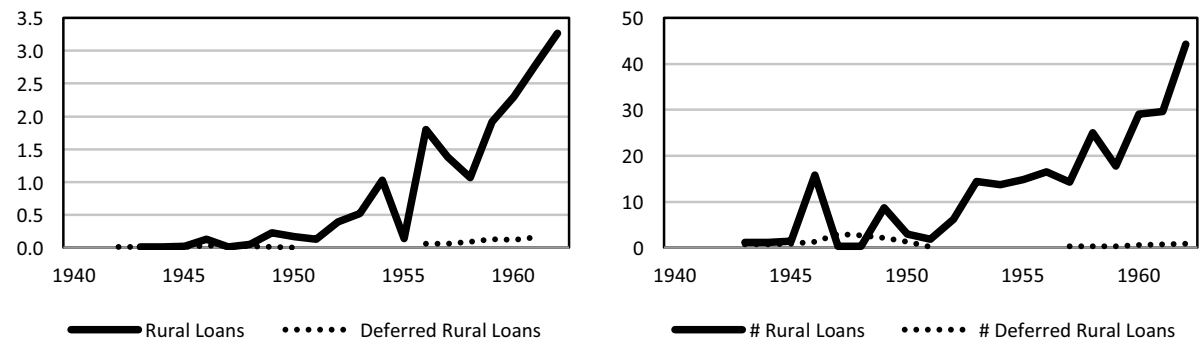

FIGURE 3

DEPOSITS AND LOANS RURAL BANKS

Notes and Sources: Computed from INE (Fondo documental del Instituto Nacional de Estadística): 3a) Anuario 1948 - Depósitos en las Cajas de Ahorro. Años 1874 a 1940 and Anuario 1966 - Confederación Española de Cajas de Ahorro Benéficas; 3b) Anuario 1961. Préstamos otorgados en el año 1960. Real prices computed using the price index series proposed by Reher and Ballesteros (1993) (Base 1930). Data for Deferred Rural Loans for the years 1952-1956 is missing. 3A): Average real value of deposits in pesetas (Base 1930). 3B) Left: Nominal value of loans in million pesetas for Spain. Right: Number of loans in Spain (thousands).

permanent increase in output prices would increase both the value of water for the farmers and for the Waterlords. ${ }^{14}$ As one can see in Figure 4B, output prices started to decrease in 1961, and they were almost back to the pre-1950s level by 1966. It is important to emphasize that: (1) by 1966, output prices were similar to the historical output prices, so we do

${ }^{14}$ Whether the increase would be greater for the farmers or the Waterlords would depend on the elasticity of demand of water and on the cross derivate between water and effort in the production function. 
A) Real Prices of water (1803-1966) in Pesetas (Base 1930)

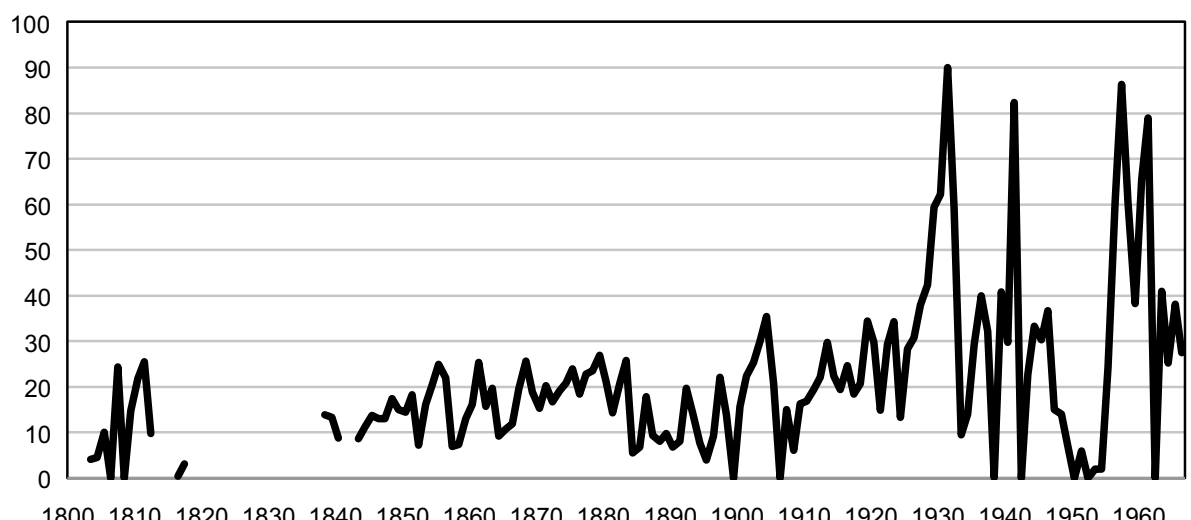

$\longrightarrow$ Real Prices of water $(1930=100)$

B) Real Prices of Agricultural Products, Pesetas $/ \mathrm{kg}(1955=100)$

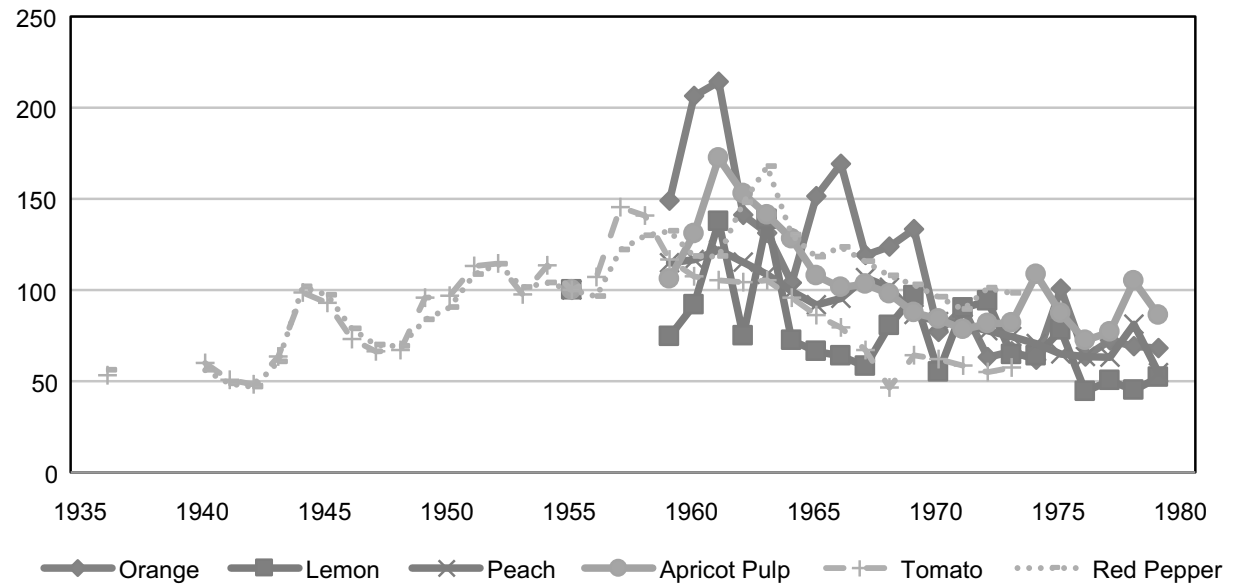

FIGURE 4

PRICES

Notes and Sources: 4A) Computed from the data from the Archivo Municipal de Mula, section Heredamiento de Aguas. Real prices computed using the price index series proposed by Reher and Ballesteros (1993) (Base 1930). 4B) Computed from data from INE (Fondo documental del Instituto Nacional de Estadística). Anuarios 1955-1978: Distribución del limonero y naranjo por provincias (orange and lemon), Albaricoque y melocotón (apricot and peach) and Patata $y$ hortalizas (tomato and red pepper). Price Index for the most common agricultural products harvested in Mula (Base 1955).

not have to worry about the ambiguity that an increase in prices produces on the relative value of water for farmers and Waterlords in 1966; and (2) there was an important increase in prices in the 1950s, thus the farmers enjoyed extraordinary profits for more than a decade, which they used to increase their savings. 
There is a concern that the increase in output prices could have increased the price of water, thereby reducing the surplus that the farmers enjoyed. Whether the water prices were affected would depend on the composition of the plots and the substitutability from one crop to another. Traditionally farmers would plant both trees and vegetables (potatoes and tomatoes). Potatoes would typically have a lower yield than trees, but the cost of not irrigating them during a dry year is just the cost of seeding. Thus, during dry years farmers would only irrigate trees and during wet years would irrigate both trees and potatoes. The impact of an increase in the value of trees' output (apricots) implies that farmers would compete for the water more fiercely in dry years. In wet years there is enough water to irrigate the trees and the competition to irrigate potatoes is not as fierce given the low value of potatoes. In other words, the marginal crops that set the equilibrium prices are apricots in dry years and potatoes in wet years. One can see in Figure 4A that indeed there were some years of high water prices in the $1950 \mathrm{~s}$, but there were also many years of low and moderate prices. Hence, given the heterogeneity in crops, the increase in output (apricot) prices induced an increase in volatility of water prices and an increase in water prices in dry years.

One can see in Figure 4A that there was an increase in the volatility of water prices after 1931. This increase in volatility would make the water rights less valuable to the Waterlords, since they are essentially financial investors, while it would reduce the value of bidding in the auction for the farmers, since water is an important input in their production function. However, the increase in volatility would have no effect on the value that the farmers assign to the water rights, because under the quotas land and water are integrated, and there are no "prices" within the farmer-firm.

\section{Ownership Distribution}

Why did each farmer not simply buy water rights and solve her own problem? According to the intuition and the model, buyers should not have waited until everyone had sufficient down payment. Richer farmers could afford to buy some water rights sooner than poorer farmers. Hence, the transition should have been gradual rather than sudden. However, as Figure 1 shows, this is not what happened. The proportion of owners with one share - an amount insufficient to irrigate the median plot in a universe of 832 shares and about 500 farmers - was constant across time at about 30 percent. Most of the owners with less than five shares were also farmers that bought shares as a way to insurance against high water prices during a drought. Those farmers would be relatively indifferent to the institution in place. The data exclude some farmers who owned no 
water at all. The distribution of shares remained unchanged by number owned over time.

Several facts could help explain this puzzle. First, wealthier farmers can retain some cash and eliminate their liquidity issues without having to buy water rights. Second, some of the gains from quotas come from internalizing externalities. In addition to the externalities mentioned earlier, there might also be organizational improvements. Since farmers and water owners are now the same people, conflicts about improving channels and rules of rationing during extreme drought will be easier to solve. Moreover, and related to the third point (discussed later), a sudden transition is easier because the lender-whether a Waterlord or a financial institution - can use the law of large numbers and eliminate the idiosyncratic risk associated with each farmer. By pooling all the claims into a single claim, the lender must still bear the aggregate risk, but not the idiosyncratic risk, plus any fixed costs that he needs to pay for each debt contract. This means that the risk premium the lender requires is lower. This pooling solution also eliminates the adverse selection problem by mutualizing debt amongst all farmers. Hence, when externalities and idiosyncratic risk are important, the set of parameters in which the transition happens suddenly outweighs the set of parameters in which the transition happens slowly. Under these conditions we expect a rapid transition.

Third, and most important, farmers began collectively asking for a loan through the Sindicato de Regantes. The purpose of a bank is to identify good investments and monitor the agent to ensure loan repayment. In this case, the Sindicato has better monitoring technology than either the Waterlords or a potential financial intermediary. The farmers, as members of this organization, were jointly responsible for the loan. Hence, the Sindicato can encourage each farmer to pay their share of the loan. Further, it can also prevent farmers from cheating by using both monetary and social sanctions. These facts may not explain why the change took place in 1966 and not earlier, but they do help us understand why the change was sudden rather than gradual.

\section{The Financial Revolution 1957-1962}

The model's last empirical prediction is that more efficient financial markets would help to solve the commitment problem faced by the Waterlords and farmers. During the 1950s and 1960s, the government's goals were to increase exports, expand the industrial sector, modernize agriculture and provide cheap credit to small businesses and households (Comín 2005, 2007). The main instrument used for these purposes 
were the Cajas de Ahorros (public savings banks). Crucially, the public savings banks only functioned as financial institutions, rather than charities, when the Ministry of Finance replaced the Ministry of Labor as regulator in 1957 (Comín 2007).

In 1962, the Bank of Spain was nationalized and new banking regulations were passed in Spain. This new legislation changed the role that savings banks played in the financial sector and increased the importance of the ICCA (Instituto de Crédito de las Cajas de Ahorros), a national agency which coordinated macro-decisions of the local saving banks. The new law also fostered banking specialization, alongside long and medium term stability. The economic growth that followed Spain's openness to international trade together with easier access to credit and a more efficient financial sector, reinforced each other in a virtuous circle. Economic growth in the 1960s enabled the savings banks to expand their operations due to growing deposits. Further, these banks diversified deposits through new regulations set forth in the Development Plans in 1964.

Figure 3B shows how both the size (left) and the number (right) of rural loans began to increase at an exponential rate in 1951. However, the change in the institution did not occur in 1951, or at any time during the 1950s. It is worth noticing that while the number and size of loans grew, the number and size of deferred loans remained negligible, suggesting that farmers were usually able to repay the loans. The rise in profits from abnormally high prices was temporary, and hence, the system's long-run inefficiency was unaltered. However, every year of high prices provided some extra profits, which farmers decided to save. By 1966, although prices had been falling for several years and had reached normal levels, farmers had accumulated enough savings to have down payments for the purchase of water rights. Further, these farmers were able to secure a loan from a public savings bank, a loan a private bank would have denied.

\section{OLD AND NEW INTERPRETATIONS OF INSTITUTIONAL DIVERSITY AND CHANGE}

Traditional explanations for institutional differences between Mula and Lorca and the rest of the towns in the region have mainly focused on geographical differences, but those explanations are not consistent with the evidence. ${ }^{15}$ In this section I explore some of these traditional

\footnotetext{
${ }^{15}$ There were other towns that also had markets for water, but those were usually for small springs and not for rivers. In particular, the towns of Bullas and Pliego, which are close to Mula, also had some markets for water (see López Férnandez and Gómez Espín 2008). However, these markets were for small water springs (La Rafa in Bullas and Los Caños in Pliego).
} 
explanations. Any explanation for the region's institutional diversity has to account for three main facts: (1) Origin: Mula and Lorca had auctions initially; (2) Persistence: the institutions in Mula and Lorca remained different than those in surrounding towns for centuries; (3) Change: Mula and Lorca switched from auctions to quotas during the 1960s.

According to the traditional hypothesis, towns with auctions were very dry, much more so than the rest of the region (Musso y Fontes 1847; Pérez Picazo and Lemeunier 1984). Arthur Maass and Raymond Anderson (1978) claimed that auctions were always more efficient than quotas, but were more costly to manage. Hence, auctions were only used when water was very scarce and valuable with respect to the costs of running an auction. ${ }^{16}$ The change in Mula implied a restriction of property rights in the form of a ban on trading. This is unusual, but there are other instances where an increased in value of the underlying asset created a change towards less markets or less defined property rights (e.g., Fenske 2014). Jean-Laurent Rosenthal (1990) showed how an institutional change was triggered by a change in the identity of those with decision power. After the French revolution, the French government used eminent domain rules to implement changes in property rights that established efficient irrigation works.

Other studies by historians such as Juan González Castaño (1992), have claimed that auctions - or disjoint property rights to water and landwere just another means by which the local elite could exert their power over the peasantry. By controlling the water, the local elite could control the non-elites. Auctions were then an effective way to exert power only in places where water was very scarce.

The problem with the arguments stated earlier is their reliance on an incorrect premise. Mula and Lorca were not drier than the towns that had quotas. Table 2 displays a representative sample of towns along the rivers in the region with irrigation communities. The most reliable data source for Mula and Lorca comes from their dams and, as one can see, their rainfall averages are around the median. If the argument were correct one would expect towns like Ulea, Fortuna, or Alguazas, all of which have quotas, to run auctions. Samuel Garrido (2011) has already presented this critique effectively. He points out that there is no correlation between weather or geography and water property rights between regions in Spain. Moreover, the co-existence of quotas and auctions characterizes all provinces of Mediterranean Spain, from the humid region of Gerona on the border with France to the desserts of Almería and Murcia

${ }^{16}$ Traditional narratives, such as Passa (1844), Aymard (1864), Díaz Cassou (1889), Brunhes (1902), and Glick (1967), either agreed with the traditional hypothesis or did not dispute it. 
TABLE 2

RAIN IN SEVERAL TOWNS IN THE MURCIA PROVINCE

\begin{tabular}{|c|c|c|c|}
\hline Town & Sample Period & Average & Standard Deviation \\
\hline Ulea & 1961-1966 & 150 & 201 \\
\hline Lorca, C. H. S. ${ }^{*}$ & $1933-2007$ & 212 & 276 \\
\hline Fortuna & $1952-2010$ & 228 & 286 \\
\hline Alguazas & $1933-1981$ & 234 & 300 \\
\hline Murcia, C. H. S. & 1933-2007 & 236 & 297 \\
\hline Jumilla & $1912-1930$ & 242 & 259 \\
\hline Lorca, Castle* & $1948-1978$ & 243 & 360 \\
\hline Librilla, C.H.S. & 1934-2010 & 260 & 350 \\
\hline Yecla & $1935-2010$ & 261 & 289 \\
\hline Mula, De La Cierva Dam* & $1933-2010$ & 262 & 362 \\
\hline Lorca, Valdeinfierno Dam* & 1933-2010 & 268 & 338 \\
\hline Totana & $1913-2010$ & 269 & 344 \\
\hline Mula, C. H. S. ${ }^{*}$ & $1953-1978$ & 274 & 343 \\
\hline Murcia, Institute & $1863-1955$ & 275 & 344 \\
\hline Blanca & $1945-2008$ & 278 & 331 \\
\hline Ricote & $1944-2010$ & 290 & 353 \\
\hline Pliego & $1954-2010$ & 306 & 394 \\
\hline Moratalla & $1933-2010$ & 308 & 356 \\
\hline
\end{tabular}

Notes and Sources: Computed from data from the AEMET (Agencia Estatal de Metereologia) and sorted by average rainfall. Monthly rainfall data measured in millimeters $(\mathrm{mm})$. C. H. S. refers to measures made by the Confederación Hidrográfica del Segura, a public regulatory agency. Towns marked with an asterisk (Mula and Lorca) had auctions while all the other towns had quotas.

in the South (López Ortiz and Melgarejo Moreno 2005). ${ }^{17}$ The argument for relative dryness takes two flavors: either towns with auctions are drier in the sense that they have lower average rain (or the same average but greater variance); or they are drier in the sense that the ratio between available water and irrigable land is lower. One can see in Table 2 that Mula and Lorca are not especially dry when compared to other towns in Murcia.

The second flavor of the relative dryness argument springs from the observation that towns with quotas have a larger amount of water available for irrigation per hectare than do towns with auctions. However, the causality is most likely reversed. When landowners had water property

\footnotetext{
${ }^{17}$ Although only Lorca and Mula were the only cities in Murcia that adopted auctions, there were other cities in all Mediterranean provinces that also adopted auctions. They were always a small minority in every province and the origin of the auctions in such places has not been explored in depth.
} 
rights, as in the quota system, there was less of an incentive to expand the irrigable land, which meant that more water was available per irrigable acre, as Mariano Ruiz-Funés (1916) pointed out. ${ }^{18}$ Moreover, as Garrido (2011) shows, the biggest increase in irrigable land that took place in all towns happened several centuries after the initial institution was put in place. The choice to have an auction or not was not a function of scarcity.

Between the fifteenth and the nineteenth century, irrigable land tripled both in towns which held auctions (Alicante and Lorca) and in Murcia where quotas were in use (Chacón Jiménez, 1979). This pattern suggests that the increase in irrigable land was due to improvement in irrigation technology. Hence, there is no evidence to support the claim that Mula and Lorca were intrinsically different than the towns around them during the thirteenth century. ${ }^{19}$ From the earlier arguments, one can feel confident that the dryness hypothesis is not true. Even if this hypothesis were true, it could only explain the initial choice of auctions and the persistence of difference. However, it cannot explain the institutional change in the 1960s unless it assumes that the weather dramatically changed in Mula and Lorca in the 1960s. It did not.

Along the same line, Rodríguez Llopis (1998) pointed out that the institutional configuration in place in each town in Murcia by the end of the Middle Ages was the outcome of the tensions between the Crown, the Castilian aristocracy, the regional nobility, and the local elites during the thirteenth century. ${ }^{20}$ Water rights were an attractive financial asset for any investor who did not want to reside in the city or work the land..$^{21}$ The original owners of water rights were the Knights of the Order of Santiago

\footnotetext{
${ }^{18}$ If the owners of the water and the owners of the land are the same people, they will restrict the size of irrigable land in order to maximize the average or total output. If the owners of the water are not the owners of the land, they will increase the amount of irrigable land beyond the point that maximizes total output, in order to maximize revenue. They will increase the amount of the irrigable land until the point at which marginal output equals average output. See Gordon (1954) for details.

${ }^{19}$ It should be noted that the first hard evidence of auctions in Mula appeared in the early sixteenth century: the minutes of the meetings of the city council in Mula mentioned the water auction. However, we do know that the rights given to the invading armies of Lorca and Mula were identical, and the first mention of water auctions in the case of Lorca date from the thirteenth century, just a few years after the siege of the city. Thus, I agree with Musso y Fontes (1847) and Rodríguez Llopis (1998) among others that, even if hard evidence is missing, it is likely that the separation of ownership between land and water occurred in Mula around the same time as in Lorca.

${ }^{20}$ This initial shock in institutions is similar to that in Chaney (2008).

${ }^{21}$ Water rights paid a flow of dividends every year, needed little monitoring and, more importantly, produced a flow payoff negatively correlated with the weather cycle: returns were high during a drought and low during rainy years. Unlike with land rights, the moral hazard problems associated with water rights are comparatively minor because the good is homogeneous and can be easily transferred to another agent. Hence, absentee lords and convents had high demand for these water rights.
} 
and the Order of the Temple, both of which had participated in the sieges of Mula and Lorca, with the Maester (Head of the Order of the Temple) taking the lion's share (Rodríguez Llopis 1998). During the modern age, and until the end of the auctions, the biggest shareholders in each town were the Nuns Convent - which received shares as donations from members of the nobility in the years after the Reconquista (711-1492) in Lorca and the Marquis of Los Vélez in Mula. As during much of the Spanish Reconquista, Christian populations were brought to the area with the goal of establishing a Christian base. Hence, the new Christian settlers in Mula started tabula rasa and created new institutions. Mula and Lorca were also frontier cities between a Christian kingdom and a Muslim kingdom, which, until the conquest of Granada in 1492, were in a constant state of war. Moreover, since the rule of these two cities was given to the ecclesiastical orders, it is not surprising that the institutions there differed from those in other towns. This hypothesis is useful in that it can reconcile institutional diversity and homogeneous geography and weather. However, it is incomplete and does not provide an answer for institutional persistence or the institutional switch in the 1960s.

Historians have argued that one of the reasons why Waterlords did not sell the water rights until the twentieth century was the lack of alternative investment opportunities (see Pérez Picazo and Lemeunier 1984). Industrialization and economic development, the argument goes, create profitable investment opportunities and thus the Waterlords want to divest in water rights and invest in industry. Although the argument is appealing and has some truth to it, it is unsatisfactory. First, it can explain why the institution persisted until the nineteenth century while there were not many alternative investment opportunities, but not why it persisted beyond periods of industrialization and modern economic activity. Second, and more fundamentally, the existence or not of alternative investment opportunities only changes the price at which the Waterlords are willing to sell, but this price will always be lower than the price that the farmers are willing to pay for the water. In other words, alternative investment opportunities affect in the same way the value of water rights for the farmers and the Waterlords, but not the relative value each of them attach to water rights.

\section{CONCLUSION}

This article explains a puzzling transition in irrigation communities in Spain, when some towns which had allocated river water through auctions switched to quotas in the 1960s. This transition is puzzling for 
two reasons. First, the transition happened in the absence of political instability or important technological changes. Second, unlike most institutional changes over the last two centuries, the allocation mechanism switched from a market institution (auctions) to a non-market institution (quotas).

The rebellion of the local governors in some towns meant that they established auctions in the thirteenth century. Due to this historical accident, they had different institutions than the rest of the towns in the area for more than 700 years. The transition was not motivated by a change in decision power over water rights or by a change in payoffs. Rather, what changed was farmers' ability to credibly commit to pay the value of their water rights to property owners. Following a temporary boom in the region's agricultural exports, and national public policy focused on easing small exporters' access to credit, farmers were able to accumulate substantial savings for the first time in centuries. They used these savings as upfront payment (collateral) to buy water rights from the Waterlords. The transition from auctions to quotas was delayed for centuries because, had farmers attempted to purchase the water rights any earlier, they could not have credibly committed to pay for them.

The inertia produced by the lack of commitment is asymmetric: a system can move from quotas to auctions at any time, but requires a specific distribution of water property rights to switch from auctions to quotas. This feature of the Institutional Inertia is not intrinsic to auctions. Rather, the model's construction requires one of the institutions to operate under a specific distribution of property rights. The model is applicable to other situations in which land or labor is the scarce resource. Thus, the framework developed here may have applications to other important phenomena in economic history such as land reform, indenture, slavery and manumission.

\section{REFERENCES}

Acemoglu, Daron, and James Robinson. "Persistence of Power, Elites, and Institutions." American Economic Review 98, no. 1 (2008): 267-93.

Alston, Lee J., Thráinn Eggertsson, and Douglass C. North. Empirical Studies in Institutional Change. Cambridge, UK: Cambridge University Press, 1996.

Archivo Municipal de Mula, Mula, Murcia, Spain.

Aymard, Maurice. Irrigations du midi de l'Espagne. Paris: Eugéne Lacroix, 1864.

Brunhes, Jean. L'irrigation dans la Péninsule Ibérique et dans l'Afrique du Nord. Paris: C. Naud, 1902.

Calatayud, Samuel, and Salvador Garrido. "The Price of Improvements: Agrarian Contracts and Agrarian Development in Nineteenth-Century Eastern Spain." Economic History Review 64, no. 2 (2011): 598-620. 


\section{Persistent Inefficient Institutions in Spain}

Chacón Jiménez, Francisco. Murcia en la centuria del Quinientos. Murcia: Universidad de Murcia-Academia Alfonso X el Sabio, 1979.

Chaney, Eric J. "Ethnic Cleansing and the Persistence of Extractive Institutions: Evidence from the Expulsion of the Moriscos." Working Paper, 2008. Available at https://scholar.harvard.edu/chaney/publications/ethnic-cleansing-and-long-termpersistence-extractive-institutions-evidence-expu.

Coase, Ronald. "The Problem of Social Cost." Journal of Law and Economics 3 (1960): 386-405.

Comín, Francisco. "El nuevo papel de la CECA y las Cajas ante las mayores exigencias de financiación del Estado (1957-1963)." Papeles de Economía Española,105/106 (2005): $27-47$.

."Spanish Saving Banks and the Competitive Cooperation Model (1928-2002)."

Revista de Historia Económica. Journal of Iberian and Latin American Economic History 25, no. 2 (2007): 199-229.

Díaz Cassou, Pedro. La Huerta de Murcia: Ordenanzas y Costumbres. Madrid: Establecimiento Tipográfico de Fortanet, 1889.

Dell, Melissa. "The Persistent Effects of Peru's Mining Mita." Econometrica 78, no. 6 (2010): 1863-903.

Donna, Javier, and José-Antonio Espín-Sánchez. "The Illiquidity of Water Markets." CSIO Working Paper No. 0124, Center for the Study of Industrial Organization, Northwestern University, Evanston, IL, 2015.

Ellickson, Robert. Order without Law: How Neighbors Settle Disputes. Cambridge: Harvard University Press, 1991.

Fenske, James. "Imachi Nkwu: Trade and the Commons." Journal of Economic History 74, no. 1 (2014): 39-68.

Fondo documental del Instituto Nacional de Estadística (INE), n.d. Available online at http://www.ine.es/inebaseweb/libros.do?tntp=25687\#.

Gale, Douglass, and Martin Hellwig. "Incentive-Compatible Debt Contracts: The One-Period Problem.” Review of Economic Studies 52, no. 2 (1985): 647-63.

Garrido, Samuel. "Governing Scarcity. Water Markets, Equity and Efficiency in pre-1950s Eastern Spain.” International Journal of the Commons 5, no. 2 (2011): 513-34.

Gil Olcina, Antonio. La Propiedad de las Aguas Perennes en el Sureste Ibérico. Alicante, Spain: Universidad de Alicante, 1993.

Glick, Thomas. Irrigation and Society in Medieval Valencia. Cambridge: Harvard University Press, 1967.

González Castaño, Juan. Una villa del Reino de Murcia en la Edad Moderna (Mula 1500-1648). Murcia, Spain: Real Academia Alfonso X el Sabio, 1992.

Gordon, H. Scott. "Theory of a Common-Property Resource: The Fishery." Journal of Political Economy 62, no., 2 (1954): 124-42.

Guiso, Luigi, Paola Sapienza, and Luigi Zingales. "Long Term Persistence." NBER Working Paper No. 14278, Cambridge, MA, 2008.

Greif, Avner. Institutions and the Path to the Modern Economy: Lessons from Medieval Trade. New York, NY: Cambridge University Press, 2006.

Hart, Oliver D. "Incomplete Contracts and the Theory of the Firm." Journal of Law, Economics \& Organization 4, no. 1 (1988): 119-39.

Hoffman, Philip T. Growth in a Traditional Society: The French Countryside 1450 1815. Princeton, NJ: Princeton University Press, 1996. 
Jha, Saumitra. "Trade, Institutions and Ethnic Tolerance: Evidence from South Asia." American Political Science Review 107, no. 4 (2013): 806-32.

Libecap, Gary D. "Economic Variables and the Development of the Law: The Case of Western Mineral Rights.” Journal of Economic History 38, no. 2 (1978): 338-62.

López Férnandez, José Antonio, and José Maria Gómez Espín. “Abastecimientos Tradicionales de Agua a los Municipios de Mula, Pliego y Bullas.” Nimbus, no. 21-22 (2008): 133-52.

López Ortiz, Maria Inmaculada, and Joaquin Melgarejo Moreno. “¿Es eficiente un mercado del agua? Algunas reflexiones a la luz de la historia de España." In Los Mercados del Agua. Análisis jurídicos y económicos de los contratos de cesión $y$ bancos de agua, edited by Joaquin Melgarejo Moreno and Andrés Molina Giménez. Spain: Thomson Civitas, 2005.

Maass, Arthur, and Raymond L. Anderson. ... and the Desert Shall Rejoice: Conflict, Growth, and Justice in Arid Environments. Cambridge: The MIT Press, 1978.

Menard, Claude, and Mary M. Shirley. Handbook of New Institutional Economics. New York: Springer, 2005.

Morilla Critz, José, Alan L. Olmstead, and Paul W. Rhode. "'Horn of Plenty': The Globalization of Mediterranean Horticulture and the Economic Development of Southern Europe, 1880-1930." Journal of Economic History 59, no. 2 (1999): $316-252$.

Musso y Fontes, José. Historia de los riegos de Lorca. Murcia, Spain: Imprenta José Carle-Palacios, 1847.

North, Douglass C. Institutions, Institutional Change and Economic Performance. Cambridge, UK: Cambridge University Press, 1990.

Ostrom, Elinor. Governing the Commons: The Evolution of Institutions for Collective Action. Cambridge NY: Cambridge University Press, 1990.

- Understanding Institutional Diversity. Princeton, NJ: Princeton University Press, 2005.

Pérez Picazo, Maria Teresa, and Guy Lemeunier. El proceso de modernización de la región murciana (siglos $X V I-X I X$ ). Murcia, Spain: Biblioteca Básica Murciana, Extra número 1, Editora Regional Murciana, 1984.

Passa (de), Francois Jaubert. Canales de Riego de Cataluña y Reino de Valencia, Leyes y Costumbres que los rigen: Reglamentos y Ordenanzas de sus principales acequias. Translation into Spanish by Juan Fiol. Valencia, Spain: Sociedad Económica de amigos del País, 1844.

Posner, Eric A. Law and Social Norms. Cambridge: Harvard University Press, 2000.

Reher, David S., and Esmeralda Ballesteros. "Precios y Salarios en Castilla la Nueva: la Construcción de un Índice de Salarios Reales: 1501-1991.” Revista de Historia Económica 11, no. 1 (1993): 101-54.

Rodríguez Llopis, Miguel. Historia de la Región de Murcia. Murcia, Spain: Editora Regional de Murcia, Monografías Regionales, 1998.

Rosenthal, Jean-Laurent. "The Development of Irrigation in Provence, 1700-1860: The French Revolution and Economic Growth.” Journal of Economic History 50, no. 3 (1990): 615-38.

Ruiz-Funés, Mariano. Derecho Consuetudinario y Economía Popular de la Provincia de Murcia. Madrid, Spain: Establecimiento Tipográfico de Jaime Rates, 1916. 
Stiglitz, Joseph E., and Andrew Weiss. "Credit Rationing in Markets with Imperfect Information." American Economic Review 71, no. 3 (1981): 393-410.

Townsend, Robert M. "Optimal Contracts and Competitive Markets with Costly State Verification." Journal of Economic Theory 21, no. 2 (1979): 265-93.

Voigtländer, Nico, and Hans-Joachim Voth. "Persecution Perpetuated: The Medieval Origins of Anti-Semitic Violence in Nazi Germany." Quarterly Journal of Economics 127, no. 3 (2012): 1339-92. 